\title{
PERLINDUNGAN HUKUM TERHADAP DESAINER GRAFIS SEBAGAI PESERTA DALAM LOMBA DESAIN GRAFIS BERDASARKAN UNDANG-UNDANG NOMOR 19 TAHUN 2002 TENTANG HAK CIPTA
}

\author{
Novi Mayasari \\ Dosen Program Studi Disain Komunikasi Visual, \\ Jurusan Disain, FSR ISI Yogyakarta \\ Email: novi_cokromiharjo@yahoo.com
}

\begin{abstract}
Copyright is essentially a part of intangible/incorporeal property which the ownership is separated from the ownership of the object. Consequently, the enactment of "the participants' works belong to the committee" clause cannot be interpreted as the transfer of both of the property rights and copyright of the works. This study is aimed to know how the graphic designer as a participant in a graphic design competition correlated with the existence of "the participants' works belong to the committee" clause is legally protected.

The data in this study were obtained by juridical-normative-empirical-research (mixture study). The data obtained from both the library research and the field research were analyzed using descriptivequalitative approach. Descriptive approach analyzes only applied at the description level in which facts were analyzes and presents in a systematic way so that it can be more easily understood and inferred. Qualitative approach doesnot emphasize its analysis on numerical data processed by the statistical method. However it doesnot mean that qualitative approach doesn't use quantitative data. The quantitative data were used but the emphasis wasnot on the hypothesis testing but rather on the attempt to answer the research question through argumentative and formal ways of thinking.

The results of this study indicate that most people, especially graphic designers didn't understand that property rights and copyright of work are two separate things and they assumed that "the participants' works belong to the committee" clause as a transfer of both property and copyright of a design. Thus often caused problems dealed were generated from the illegal use by the committee such as the use of the works without the cretor's permission, the committee's decision that the competition had no winner or that the prize is distributed evenly to all the nominees.
\end{abstract}

\section{Keywords : Copyright, Design, Graphic Design}

\section{Pendahuluan}

Disain Grafis sering juga disebut sebagai Desain Komunikasi Visual yang merupakan bagian dari seni terapan yang berkaitan dengan rancangan komunikasi yang bersifat kasat mata, merupakan salah satu bidang yang berkembang pesat akhir-akhir ini. Perkembangan dalam dunia disain grafis ini merupakan jawaban dari perkembangan dunia ekonomi yang semakin pesat. Sebagai bagian dari sarana komunikasi secara visual yang meliputi berbagai bidang seperti reklame, corporate identity, periklanan, komputer grafis, dan sebagainya, desain grafis memegang peranan penting dalam promosi sebuah usaha.

Berkembangnya bidang desain grafis tentu saja di ikuti oleh banyaknya lomba-lomba desain grafis seperti lomba logo, lomba animasi, ilustrasi dan lain sebagainya. Perlombaanperlombaan ini selain dapat dijadikan ajang kompetensi untuk menilai kemampuan para desainer grafis juga dapat mendatangkan keuntungan secara ekonomis bagi para pemenang. Seringkali panitia menyediakan hadiah yang cukup tinggi bagi para pemenang sebagai reward/penghargaan.

Tentu saja sebelum mengikuti perlombaan-perlombaan tersebut peserta harus memenuhi beberapa persyaratan yang telah ditentukan oleh panitia, seperti spesifikasi karya, jumlah karya, dan lain-lain. Peserta juga 
diharuskan mengisi dan menandatangani formulir yang telah disediakan panitia sebagai bentuk persetujuan keikutsertaan dalam perlombaan. Penandatanganan formulir tersebut merupakan suatu bentuk perjanjian kepesertaan dalam lomba desain grafis. Dalam perjanjian tersebut penulis seringkali menemukan adanya pencatuman klausula "karya peserta menjadi milik panitia".

Keberadaan klausula tersebut dalam perjanjian kepesertaan lomba desain grafis menuntut kepada semua peserta lomba baik yang menang mapun yang kalah untuk menyerahkan karyanya kepada panitia/penyelenggara. Penyerahan karya peserta tersebut sering diartikan oleh banyak pihak sebagai penyerahan hak cipta at as karya dengan demikian panitia/penyelenggara dapat menggunakan karya dari peserta tersebut tanpa izin.

Beberapa waktu lalu muncul sebuah kasus terkait dengan lukisan wajah dalam pecahan uang sepuluh ribu rupiah. Kasus tersebut berkaitan dengan dimuatnya lukisan wajah Sultan Badaruddin Sah II dalam pecahan uang sepuluh ribu rupiah yang dikeluarkan oleh Bank Indonesia tanpa ijin Eden Arifin sebagai pencipta. Sebagaimana diberitakan oleh vivanews.com, "penggunaan gambar Sultan Badaruddin II di uang kertas tersebut saat itu sempat menjadi kasus pelanggaran hak cipta, diduga gambar tersebut digunakan tanpa izin pelukisnya. (Vivanews.com, Diakses tanggal 1Februari 2011 pukul 22.00 WIB.)

Berkaca dari kasus lukisan Sultan Mahmud Badaruddin II, kita bisa melihat kurangnya pemahaman masyarakat tentang konsep hak cipta. Hak cipta adalah bagian dari hak milik yang bersifat abstrak (incorporeal property), yang merupakan penguasaan atas hasil kemampuan kerja, dan gagasan serta hasil pikiran
(Djumhana, Djubaedillah, 2003: 56). Jadi kepemilikan terhadap hak cipta tidaklah melekat pada karya tetapi melekat pada ide dan gagasan serta kemampuan kerja pencipta dalam menciptakan karya tersebut.

Sebagaimana dijelaskan oleh L.j. Taylor (2003: 54) bahwa hak cipta melindungi ekspresi dari sebuah ide, bukan melindungi idenya sendiri. Hak cipta adalah hak yang melindungi ide pencipta yang telah diwujudkan dalam bentuk sebuah karya. Dengan demikian kepemilikan hak milik atas sebuah karya dan kepemilikkan hak cipta atas karya tersebut adalah dua hal yang berbeda. Seorang pencipta boleh saja menjual karyanya, namun bukan berarti dia kehilangan hak cipta atas karya tersebut kecuali telah terjadi pengalihan hak cipta.

\section{Pembahasan}

\section{Desainer Grafis sebagai Pencipta dalam Lomba Desain Grafis}

Desainer grafis sebagai pembuat karya desain merupakan seorang pencipta berdasarkan pasal 1 ayat (3) Undang-undang Hak Cipta. Seorang pencipta harus mempunyai kualifikasi tertentu, agar hasil karyanya dapat dilindungi. Dia harus memiliki identitas serta status untuk menentukan kepemilikkan hak. Pada dasarnya seseorang yang membuahkan karya tertentu adalah pemilik hak cipta (Djumhana, Djubaedillah, 2003: 64). Pencipta adalah seorang atau beberapa orang secara bersama-bersama atas inspirasinya melahirkan suatu Ciptaan berdasarkan kemampuan pikiran, imajinasi, kecekatan, ketrampilan, atau keahlian yang dituangkan ke dalam bentuk yang khas dan bersifat pribadi.

Orang yang menciptakan sesuatu bentuk ciptaan, dianggap dialah yang memiliki hak cipta 
tersebut kecuali ditentukan lain. Dalam konteks hukum yang dianggap sebagai pencipta adalah orang yang namanya disebut dalam ciptaan atau diumumkan sebagai pencipta pada suatu ciptaan, juga orang yang namanya terdaftar dalam daftar umum ciptaan dan pengumuman resmi (2003: 64).

Dalam perlombaan desain grafis, Desainer grafis pada dasarnya merupakan pencipta berdasarkan pasal 5 ayat (1) huruf b di atas karena biasanya karya yang disertakan dalam lomba tidak didaftarkan sehingga tidak tercantum dalam daftar umum ciptaan sehingga satu-satunya pembuktian adalah pencantuman nama dalam karya peserta.

\section{Ciptaan dalam Desain Grafis}

Desain Grafis merupakan suatu bidang desain yang memiliki cakupan garapan yang cukup luas. Karya-karya desain grafis yang mendapatkan perlindungan hak cipta adalah:

1) Pasal 12 (1) huruf a yaitu pamflet serta perwajahan karya tulis (lay out).

2) Pasal 12(1) huruf c yaitu alat peraga yang dibuat untuk kepentingan pendidikan dan ilmu pengetahuan;

3) Pasal 12 (1) huruf f yaitu seni rupa dalam segala bentuk seperti seni lukis, gambar dan seni terapan

4) Pasal 12 ayat (1) huruf h yaitu peta

5) Pasal 12 ayat (1) huruf $\mathrm{j}$ yaitu karya fotografi

6) Pasal 12 ayat (1) huruf $k$ yaitu Sinematrografi

7) Pasal 12 ayat (1) huruf 1 yaitu hasil karya pengalihwujudan.

8) Pasal 19 yang mengatur mengenai potret yaitu gambar dari wajah orang yang digambarkan, baik bersama bagian tubuh lainnya ataupun tidak, yang diciptakan dengan cara dan alat apapun.

Hak cipta atas ciptaan-ciptaan di atas didapat secara otomatis setelah seorang pencipta menciptakan suatu karya/ciptaan itu diwujudkan dalam bentuk yang nyata karena walaupun hak cipta merupakan hasil intelektual manusia namun harus sudah dalam bentuk suatu karya nyata. Hal ini seseuai dengan ketentuan pasal 2 ayat (1) UU Hak Cipta yaitu:

"hak cipta merupakan hak eksklusif bagi Pencipta atau Pemegang Hak Cipta untuk mengumumkan atau memperbanyak Ciptaannya, yang timbul secara otomatis setelah suatu ciptaan dilahirkan tanpa mengurangi pembatasan menurut peraturan perundang-undangan yang berlaku."

Oleh karena kepemilikkan hak cipta terjadi secara otomatis maka pendaftaran ciptaan tidak merupakan suatu kewajiban untuk mendapatkan hak cipta. Namun demikian pencipta maupun pemegang hak cipta yang mendaftarkan ciptaannya akan mendapatkan surat pendaftaran ciptaan yang dapat dijadikan sebagai alat bukti awal di pengadilan apabila timbul sengketa di kemudian hari terhadap ciptaan tersebut (Panduan HKI, 2006: 14).

\section{Masa Berlaku Hak Cipta Atas Karya Desain Grafis}

Perlindungan hukum terhadap suatu hak cipta bersifat terbatas dan tidak berlaku selamanya, dalam arti setelah habis masa perlindungannya karya cipta tersebut akan menjadi milik umum. Jangka waktu perlindungan untuk masing-masing ciptaan berbeda-beda tergantung jenis ciptaannya. Jangka waktu perlindungan terhadap karya desain grafis berdasarkan Undang-undang Hak Cipta Nomor 19 Tahun 2002 adalah:

1) Berdasarkan Pasal 29 ayat (1) Hak Cipta atas Ciptaan: 
a) Buku, pamflet, dan semua hasil karya tulis lain;

b) Segala bentuk seni rupa, seperti gambar, kolase dan seni terapan;

c) Alat peraga;

d) Peta;

Berlaku selama hidup Pencipta dan terus berlangsung hingga 50 (lima puluh) tahun setelah Pencipta meninggal dunia. Sedangkan dalam pasal 29 (2) dijelaskan bahwa untuk ciptaan-ciptaan yang termasuk ke dalam pasal 29 ayat (1) yang dimiliki oleh 2 (dua) orang atau lebih, Hak Cipta berlaku selama hidup Pencipta yang meninggal dunia paling akhir dan berlangsung hingga 50 (lima puluh) tahun sesudahnya.

2) Selanjutnya disebutkan dalam pasal 30 ayat (1) bahwa untuk ciptaan-ciptaan berupa:
a) Program komputer
b) Sinematografi
c) Fotografi
d) Karya hasil pengalihwujudan

Berlaku selama 50 (lima puluh) tahun sejak pertama kali terbitkan.

3) Sedangkan Hak Cipta atas perwajahan karya tulis yang diterbitkan berdasarkan pasal 30 ayat (2) juga berlaku selama 50 (lima puluh) sejak pertama kali diterbitkan. Lebih jauh dijelaskan dalam pasal 30 ayat (30) bahwa untuk ciptaan sebagaimana dimaksud dalam ayat (1) dan (2) maupun dalam pasal 29 (1) yang dimiliki oleh badan hukum berlaku selama 50 (lima puluh) tahun sejak ciptaan tersebut pertama kali diterbitkan.

Hak-hak yang Dimiliki Desainer Grafis sebagai Pencipta

Pencipta sebagai pemilik hak cipta berdasarkan pasal 1 ayat (4) disebut sebagai pemegang hak cipta. Pencipta sebagai pemegang hak cipta berdasarkan pasal 2 ayat (1) Undangundang Hak Cipta memiliki hak eksklusif untuk mengumumkan atau memperbanyak ciptaan. Hak eksklusif yang dimaksud dalam pasal tersebut adalah hak yang semata-mata diperuntukkan bagi pemegangnya sehingga tidak ada pihak lain yang boleh memanfaatkan hak tersebut tanpa izin pemegangnya.

Hak cipta memberikan hak kepada penciptanya untuk mendapatkan keuntungan ekonomi dari karya ciptaannya (hak ekonomi). Menurut Undang-undang Hak Cipta hak ekonomi tersebut meliputi hak untuk mengumumkan dan hak untuk memperbanyak ciptaan.

Selain memiliki hak untuk mengumumkan atau memperbanyak, Pemilik hak cipta juga memiliki hak untuk melarang pihak lain untuk mengumumkan atau memperbanyak ciptaan tanpa izin pemilik hak cipta, sebagaimana dicontohkan dalam pasal 2 ayat (2) disebutkan bahwa Pencipta dan/atau Pemegang Hak Cipta atas karya sinematografi, dan program komputer memiliki hak untuk memberikan izin atau melarang orang lain yang tanpa persetujuan menyewakan ciptaan tersebut untuk kepentingan yang bersifat komersial.

Selain mendapatkan perlindungan terhadap hak ekonominya, seorang pencipta juga mendapatkan perlindungan terhadap hak moralnya sebagaimana diatur dalam pasal 24 Undang-undang Nomor 19 tahun 2002 tentang Hak Cipta.

Lebih jauh dijelaskan bahwa dengan hak moral, Pencipta dari suatu karya memiliki hak untuk:

1) Dicantumkan nama atau nama samarannya di dalam Ciptaannya 
ataupun salinannya dalam hubungan dengan penggunaan secara umum.

2) Mencegah bentuk-bentuk distorsi, mutilasi dan bentuk perubahan lainnya yang meliputi pemutarbalikkan, pemotongan, perusakkan, penggantian yang berhubungan dengan karya cipta yang pada akhirnya akan merusak apresiasi dan reputasi Pencipta.

\section{Pelanggaran Hak Cipta}

Pelanggaran hak cipta diatur dalam UU Hak Cipta. Pelanggaran tersebut dapat berupa perbuatan mengambil, mengutip, merekam, memperbanyak, atau mengumumkan sebagian atau seluruh ciptaan orang lain tanpa izin Pencipta/Pemegang Hak Cipta, atau yang dilarang Undang-undang, atau melanggar perjanjian. (Muhammad, 2007:240)

Dilarang undang-undang artinya bahwa undang-undang tidak memperkenankan perbuatan itu dilakukan karena:

1) Merugikan Pencipta atau Pemegang Hak Cipta, misalnya memfotocopy sebagian ciptaan orang lain kemudian dijualbelikan kepada masyarakat; atau

2) Merugikan kepentingan negara, misalnya mengumumkan ciptaan yang bertentangan dengan kebijaksanaan pemerintah di bidang pertahanan keamanan; atau

3) Bertentangan dengan ketertiban umum dan kesusilaan, misalnya memperbanyak dan menjual ved porno.
Sedangkan menurut siaran Ikatan Penerbit Indonesia (Ikapi) 15 Februari 1984, kejahatan pelanggaran hak cipta dibedakan menjadi dua macam, yaitu:

1) Mengutip sebagian ciptaan orang lain dan dimasukkan ke dalam ciptaan sendiri seolah-olah itu ciptaan sendiri atau mengakui ciptaan orang lain seolah-olah itu ciptaan sendiri tanpa menyebutkan sumbernya. Perbuatan ini disebut plagiat atau penjiplakan (plagiarism).

2) Mengambil ciptaan orang lain untuk diperbanyak dan diumumkan sebagaimana aslinya tanpa mengubah bentuk, isi, Pencipta, ataupun penerbit/perekam. Perbuatan ini disebut pembajakkan atau piracy. (Muhammad, 2007:241)

\section{Pemahaman Masyarakat Terhadap Adanya}

Klausula "karya peserta menjadi milik panitia" Dalam Perjanjian Kepesertaan

\section{Lomba Desain Grafis}

Masyarakat dalam hal ini adalah desainer grafis merupakan subjek penting dalam perjanjian kepersertaan lomba desain grafis. Sebagai desainer yang merupakan pencipta dalam lomba desain, para desainer seringkali mendapatkan permasalahan yang timbul akibat kekurangpahaman terhadap adanya klausula "karya peserta menjadi milik panitia". Padahal klausula tersebut banyak sekali ditemukan dalam berbagai lomba desain grafis. Hal ini tercermin dari jawaban para responden berikut ini.

TABEL 1

JAWABAN WAWANCARA

\begin{tabular}{|c|c|c|c|}
\hline Pertanyaan & Sering & Jarang & $\begin{array}{c}\text { Tidak } \\
\text { Pernah }\end{array}$ \\
\hline $\begin{array}{l}\text { Apakah anda sering menemukan adanya klausula } \\
\text { "karya peserta menjadi milik panitia dalam } \\
\text { formulir lomba desain grafis? }\end{array}$ & $\begin{array}{c}15 \\
(100 \%)\end{array}$ & 0 & 0 \\
\hline
\end{tabular}

Sumber: Data Tahun 2012 
Jawaban responden menunjukkan bahwa seluruh responden yang berjumlah lima belas orang (100\%) sering menemukan bahwa dalam formulir lomba desain grafis terdapat adanya klausula "karya peserta menjadi milik panitia". Namun lebih jauh disebutkan bahwa beberapa responden juga menemukan bahwa beberapa panitia lomba menambahkan klausula dibelakang klausula tersebut untuk memperjelas.

Banyak diantara para desainer tersebut masih mengganggap bahwa dengan adanya klausula tersebut berarti bahwa mereka harus menyerahkan hak cipta karyanya kepada panitia, dengan demikian panitia bebas untuk menggunakan karya tersebut demi kepentingannya. Para desainer tersebut mengganggap bahwa hal tersebut merupakan resiko ketika mengisi formulir lomba dan menyatakan kesediaannya.

Sebanyak 14 responden $(93,3 \%)$ menjawab bahwa mereka harus menyerahkan karyanya kepada panitia sedangkan 1 orang responden (6,7\%) yaitu Edy Jatmiko berpendapat bahwa seharusnya karya pemenang saja yang menjadi milik panitia sedangkan karya peserta yang kalah harus dikembalikan. (Wawancara dengan Edy jatmiko pada tanggal 14 April 2012)

Sebagai hak milik yang bersifat abstrak (incoporeal property, intangible property), hak cipta merupakan kekayaan yang dihasilkan oleh intelektualita manusia. Dengan demikian hak cipta bukanlah hak milik yang bersifat kebendaan sebagaimana tanah, mobil dan rumah. Menurut Abdulkadir Muhammad (2007:2), hasil kemampuan berpikir (intellectual) manusia merupakan ide yang kemudian dijelmakan dalam bentuk ciptaan. Pada ide tersebut melekat predikat intelektual yang bersifat abstrak.

Hak Cipta pada hakekatnya merupakan hak milik yang tidak berwujud (incorporeal property, intangible property) yang kepemilikkannya terpisah dengan kepemilikkan atas bendanya. Dengan demikian berlakunya klausula "karya peserta menjadi milik panitia" tidak dapat diartikan sebagai penyerahan hak milik atas karya sekaligus hak cipta atas karya tersebut karena keduanya merupakan dua hal yang terpisah. Namun sayangnya di dalam praktek seringkali terjadi kesalahpahaman bahwa antara hak cipta dan hak milik atas benda ciptaan adalah satu kesatuan yang tak terpisahkan sehingga seringkali masyarakat menganggap bahwa jual beli suatu karya seni berarti pula berpindah hak ciptanya.

Kesalahpahaman ini pulalah yang terjadi dalam berbagai macam lomba desain grafis. Sebagaian besar responden yang merupakan desainer belum memahami bahwa hak cipta

TABEL 2

JAWABAN WAWANCARA

\begin{tabular}{|c|c|c|}
\hline Pertanyaan & $\mathrm{Ya}$ & Tidak \\
\hline $\begin{array}{l}\text { Apakah dengan adanya klausula"karya peserta } \\
\text { menjadi milik panitia" berarti hak milik karya anda } \\
\text { menjadi milik panitia? }\end{array}$ & $\begin{array}{c}14 \\
(93,3 \%)\end{array}$ & $\begin{array}{c}1 \\
(6,7 \%)\end{array}$ \\
\hline
\end{tabular}

Sumber: Data Tahun 2012 
terpisah dari hak milik atas karya. Sehingga ketika ketika mereka menandatangani formulir lomba desain grafis yang didalamnya terdapat klausula "karya peserta menjadi milik panitia", maka mereka juga mengganggap bahwa hal tersebut berarti memberikan hak cipta atas karyanya. Dari 15 (lima belas) orang desainer yang menjadi responden 13 diantaranya menjawab ya atas pertanyaan “ Apakah dengan adanya klausula karya peserta menjadi milik panitia tersebut berarti hak cipta atas karya juga berpindah kepada panitia?"

Jawaban responden tersebut menunjukkan bahwa 86,75 dari responden tidak memahami bahwa perpindahan hak milik kepada panitia bukan berarti berpindah pula hak cipta atas karya tersebut karena kepemilikkan atas keduanya merupakan suatu hal yang terpisah. Hanya 2 orang atau $13,3 \%$ responden saja yang menyatakan bahwa dengan adanya klausula tersebut bukan berarti bahwa hak cipta atas karya juga berpindah.
Ketidakpahaman para responden terhadap konsep hak cipta terpisah dengan hak milik atas benda perwujudannya tersebut menjadikan sebagian besar reponden mengganggap bahwa adanya "klausula karya peserta menjadi milik panitia" dalam perjanjian tersebut merugikan. Sebanyak 73,3\% responden atau 11 (sebelas) responden menjawab ya untuk pertanyaan "Menurut anda apakah adanya klausula karya peserta menjadi milik panitia tersebut merugikan bagi desainer?" dan hanya 4 (empat) orang responden atau $26,7 \%$ yang menjawab tidak.

Hal ini menunjukkan bahwa pemahaman masyarakat terhadap konsep mengenai hak cipta sebagai bagian hak milik yang tidak berwujud dan terpisah dari benda ciptaannya masih sangat kurang, bahkan hakim Mahkamah Agung yang memutus kasus sengketa sketsa wajah Sultan Mahmud Baddarudin II yang merupakan desain hasil karya Eden Arifin saja memenangkan pihak panitia (Pemda Sumatera Selatan) dimana dalam

TABEL 3

JAWABAN WAWANCARA

\begin{tabular}{|l|c|c|}
\hline Pertanyaan & Ya & Tidak \\
\hline $\begin{array}{l}\text { Apakah dengan adanya klausula karya peserta menjadi milik panitia } \\
\text { tersebut berarti hak cipta atas karya juga berpindah kepada panitia? }\end{array}$ & $\begin{array}{c}13 \\
(86,7 \%)\end{array}$ & $\begin{array}{c}2 \\
(13,3 \%)\end{array}$ \\
\hline
\end{tabular}

Sumber: Data Tahun 2012

TABEL 4

JAWABAN WAWANCARA

\begin{tabular}{|l|c|c|}
\hline Pertanyaan & Ya & Tidak \\
\hline $\begin{array}{l}\text { "Menurut anda adanya klasusula karya peserta menjadi milik } \\
\text { panitia tersebut merugikan bagi desainer?" }\end{array}$ & 11 & 4 \\
$(73,3 \%)$ & $(26,7 \%)$ \\
\hline
\end{tabular}

Sumber: Data Tahun 2012 
kasus tersebut hakim memutuskan bahwa karya milik Eden Arifin tersebut telah berpindah hak Ciptanya kepada Pemda Sumatera Selatan sebagai penyelenggara lomba dan sebagai gantinya pihak Eden Arifin sudah mendapatkan hadiah pertama sebesar Rp.50.000,00 dalam kompetisi tersebut (Vivanews.com, Diakses 1Februari 2011 pukul 22.00 WIB).

Akibat Hukum dari Adanya Klausula "karya peserta menjadi milik panitia" dalam Perjanjian kepesertaan Lomba Desain Grafis.

Adanya klausula karya peserta menjadi milik panitia dalam perjanjian desain grafis akan sangat rentan menimbulkan berbagai bentuk pelanggaran Hak Cipta. Hal ini karena keberadaan klausula tersebut seringkali ditafsirkan sebagai berpindahnya Hak Cipta atas ciptaan. Permasalahan seringkali timbul karena kurangnya pemahaman peserta mengenai adanya klausula

TABEL 5

JAWABAN WAWANCARA

\begin{tabular}{|l|c|c|}
\hline Pertanyaan & Pernah & Tidak Pernah \\
\hline $\begin{array}{l}\text { Apakah anda pernah mengalami permasalahan terkait adanya } \\
\text { "klausula karya peserta menjadi milik panitia" tersebut? }\end{array}$ & $\begin{array}{c}6 \\
(40 \%)\end{array}$ & $\begin{array}{c}9 \\
(60 \%)\end{array}$ \\
\hline
\end{tabular}

Sumber: Data Tahun 2012

tersebut. Para desainer yang menjadi peserta ratarata memahami klausula tersebut sebagai penyerahan hak milik maupun hak cipta atas karya yang mereka sertakan dalam perlombaan tersebut. Hampir seluruh desainer yang menjadi responden penulis memiliki pemahaman bahwa Hak Cipta dan Hak Milik adalah satu kesatuan dengan demikian ketika karya sudah diserahkan dan perjanjian yang mengandung klausula di atas ditanda tangani maka secara otomatis kepemilikkan atas karya tersebut berpindah dan panitia berhak untuk mengeksploitasi karya tersebut.

Ketidakpahaman itulah yang kemudian seringkali menimbulkan permasalahan dalam lomba desain grafis. Berbagai permasalahan yang timbul akibat adanya klausula karya peserta menjadi milik panitia tersebut seringkali diakibatkan oleh adanya penyalahgunaan karya oleh panitia. Dalam arti bahwa permasalahan timbul karena adanya itikad tidak baik dari pihak panitia. Berbagai permasalahan yang timbul tersebut diantaranya:

1. Penggunaan karya tanpa ijin pencipta

2. Pengumuman tidak adanya pemenang dalam suatu lomba

3. Pemenang Bersama

Permasalahan-permasalahan tersebut sering menimpa para desainer yang menjadi peserta dalam lomba desain grafis sebagaimana tergambar dalam tabel di bawah ini:

\section{Penggunaan Karya Tanpa izin Pencipta}

Penggunaan karya tanpa izin ini bisa terjadi terhadap karya pemenang maupun bukan karya pemenang. Dalam hal ini panitia menggunakan karya bukan hanya untuk tujuan publikasi, promosi atau tujuan lomba sebelumnya tapi dimanfaatkan untuk mendapatkan keuntungan ekonomis seperti misalnya dijual kepada pihak lain. Beberapa responden pernah menemukan karya yang dikutsertakan dalam suatu lomba ternyata digunakan oleh pihak lain yang bukan panitia lomba tanpa izin mereka. Sebanyak dua 
orang responden atau $13,3 \%$ pernah mengalami hal ini.

2. Pengumuman Tidak Ada Pemenang Dalam Suatu Lomba

Beberapa desainer yang menjadi responden dalam penelitian ini pernah mengalami permasalahan ini, dimana dalam suatu lomba dinyatakan tidak ada pemenang sehingga tidak ada satupun peserta lomba yang memperoleh hadiah. Alasan yang seringkali digunakan oleh panitia adalah bahwa karya para peserta tidak memenuhi standar yang diharapkan oleh panitia. Dalam masalah ini ada dua hal yang seringkali terjadi, pertama panitia akan tetap menggunakan karya salah seorang peserta yang dianggap layak atau panitia akan mengoplos karya peserta untuk dijadikan satu karya yang baru.

a. Menggunakan karya peserta tanpa ijin

Panitia menggunakan karya salah satu peserta tanpa ijin dan tanpa memberikan hadiah walaupun karya tersebut digunakan. Dalam hal ini panitia dapat menggunakan karya tersebut dalam bentuk yang orisinil tanpa perubahan jadi sama persis dengan karya yang dikirimkan peserta atau melakukan beberapa perubahan terhadap karya. Namun, seringkali alternatif kedualah yang digunakan, jadi panitia akan menggunakan karya salah seorang peserta, memodifikasinya sedikit dan bisa dengan meminjam jasa desainer profesional untuk memperbaiki karya tersebut sesuai yang mereka inginkan.

Penyalahgunaan seperti ini paling sering terjadi dalam lomba logo, dimana logo merupakan salah satu aset penting bagi suatu perusahaan maupun instansi. Salah seorang responden, Bapak Baskoro, pernah beberapa kali mengikuti lomba logo yang akhirnya dinyatakan tidak ada pemenang namun beberapa waktu kemudian ternyata karya respondenlah yang digunakan. Menurut paparan beliau, pada tahun 1983, bapak Baskoro pernah mengikuti lomba Logo suatu Departemen, dimana pada waktu itu logo masih dibuat secara manual sehingga beliau tidak memiliki data aslinya. Setelah beberapa waktu ternyata tidak ada pengumuman dari pihak penyelenggara karena itu beliau berinisiatif untuk menelpon pihak panitia, namun ternyata pihak panitia menyatakan bahwa tidak ada pemenang dalam lomba tersebut. (Wawancara dengan Baskoro Suryo Banindro pada tanggal 17 April 2012) Setengah bulan kemudian ternyata muncul logo baru dari pihak departemen penyelenggara lomba yang sangat mirip dengan logo beliau.

Senada dengan bapak Baskoro, bapak Gogor juga pernah mengalami kejadian yang serupa pada tahun 1996 dimana dalam lomba Logo sebuat Stasiun TV dinyatakan tidak ada pemenang, namun ternyata karya yang muncul merupakan gabungan dari lima karya nominasi milik peserta. Namun pada waktu itu karena karya masih dibuat secara manual maka peserta mengalami kesulitan untuk menunjukkan bukti karya aslinya (Wawancara dengan P. Gogor Bangsa pada tanggal 15 April 2012)

Begitu pula dengan Terra Bajraghosa dimana logonya yang digunakan oleh sebuah yayasan Nirlaba merupakan logo yang disertakan dalam lomba dinyatakan tidak ada pemenang. Namun, karena logo tersebut adalah untuk sebuah yayasan nirlaba maka Terra merelakannya dan tidak menuntut haknya. 
b. Mengoplos Karya peserta

Mengoplos karya atau lebih tepatnya menggabungkan beberapa karya peserta menjadi suatu karya baru. Biasanya dalam hal ini panitia akan memilih karya beberapa peserta yang dirasa tepat, kemudian menyewa jasa desainer untuk menggabungkan karya-karya tersebut menjadi karya baru yang lebih menarik. Menurut Bapak Gogor, hal ini paling sering terjadi pada kasus pitching iklan, dimana dari beberapa peserta dinyatakan tidak ada pemenang kemudian peserta diberikan pitching fee sebagai pengganti biaya cetak. Namun yang terjadi kemudian pihak perusahaan akan menyewa jasa biro iklan atau desainer freelance yang akan mengambil beberapa bagian dari karya iklan para peserta untuk kemudian dijadikan satu. Cara ini lebih murah daripada perusahaan harus membayar pemenang pitching. (Wawancara dengan P.Gogor Bangsa pada tanggal 15 April 2012)

Hari Mulyanto, salah seorang kolega bapak Baskoro yang saat ini bekerja sebagai desainer di Jakarta, beberapa waktu lalu mengalami kejadian yang hampir sama. Dalam lomba logo yang diikutinya, dinyatakan tidak ada pemenang, namun ternyata logo dari pihak penyelenggra yang baru merupakan gabungan dari desain logo lama instansi tersebut dengan logo yang dikirimkannya untuk lomba. Saat ini Hari Mulyanto sedang mencari cara untuk meminta pertanggungjawaban pihak penyelenggara yang telah menggunakan logonya tersebut (Informasi seputar kasus Hari Mulyanto melalui Baskoro Suryo Banindro pada tanggal 18 Juli 2012)

\section{c. Pemenang Bersama}

Terkadang dalam sebuah lomba dinyatakan adanya pemenang bersama dimana seluruh nominasi peserta tidak ditentukan juara bersama dan hanya ditentukan sebagai pemenang bersama dengan demikian hadiah dibagi rata diantara para nominator. Setelah itu panitia biasanya akan menggabungkan karya para nominator menjadi sebuah karya baru. Sebanyak dua orang responden $(13,3 \%)$ pernah mengalami hal tersebut.

Permasalahan yang terjadi tersebut tentu saja sangat merugikan para desainer, namun hampir seluruh responden yang mengalami kasus-kasus di atas mengaku tidak pernah mengambil jalur hukum untuk menyelesaikan masalahnya. Biasanya mereka hanya berinisiatif untuk meminta keterangan dan konfirmasi dari panitia sebagaimana yang dilakukan oleh bapak yang tidak melakukan upaya hukum karena pada waktu itu tidakpaham upaya hukum apa yang harus dilakukan untuk menuntut haknya sebagai peserta yang logonya digunakan oleh panitia. Upaya yang beliau lakukan hanya sebatas korespodensi melalui surat atau menelpon pihak panitia untuk meminta konfirmasi yang ternyata tidak mendapatkan tanggapan (Wawancara dengan Baskoro Suryo Banindro pada tanggal 15 April 2012)

\section{Kesimpulan}

Dalam perlombaan desain grafis, Desainer grafis pada dasarnya merupakan pencipta berdasarkan pasal 5 ayat (1) huruf b di atas karena biasanya karya yang disertakan dalam lomba tidak didaftarkan sehingga tidak tercantum dalam daftar umum ciptaan sehingga satu-satunya 
pembuktian adalah pencantuman nama dalam karya peserta. Sebagai seorang pencipta maka desainer grafis memiliki hak untuk mendapatkan perlindungan terhadap hak ekonomi maupun hak moralnya sebagaimana diatur dalam Undangundang Nomor 19 Tahun 2002 tentang Hak Cipta.

Adanya klausula karya peserta menjadi milik panitia dalam perjanjian desain grafis akan sangat rentan menimbulkan berbagai bentuk pelanggaran Hak Cipta. Hal ini karena keberadaan klausula tersebut seringkali ditafsirkan sebagai berpindahnya Hak milik sekaligus Hak Cipta atas karya. Dari 15 responden sebanyak 13 responden atau $86,7 \%$ menjawab bahwa adanya klausula "karya peserta menjadi milik panitia hak milik karya berarti pula berpindahnya hak cipta atas karya tersebut. Bahkan narasumber dari Kantor Wilayah Hukum dan Hak Asasi Manusia Daerah Istimewa Yogyakarta juga menyebutkan bahwa adanya klausula tersebut berarti kepemilikkan atas karya sekaligus hak ciptanya berpindah kepada panitia.

Kesalahpahaman konsep kepemilikkan hak cipta yang terpisah dari hak milik atas bendanya itulah yang seringkali menimbulkan permasalahan dalam lomba desain grafis. Beberapa permasalahan yang seringkali menimpa para desainer terkait adanya klausula"karya peserta menjadi milik panitia" dalam perjanjian kepesertaan lomba desain grafis adalah: penggunaan karya tanpa ijin pencipta, pengumuman tidak adanya pemenang dalam suatu lomba, pemenang bersama. 


\section{Daftar Pustaka}

Abdulkadir Muhammad, Kajian Hukum Ekonomi Hak Kekayaan Intelektual, 2007, Citra Aditya Bakti, Bandung.

, Buku Panduan Hak Kekayaan Intelektual, 2006, Direktorat Jenderal Hak Kekayaan Intelektual, Jakarta.

M. Djumhana dan R. Djubaedillah, 2003, Hak Milik Intelektual, seajarah, teori dan Prakteknya di Indonesia, Citra Aditya Bakti, Bandung.

Saifuddin Anwar, 2005Metode Penelitian, Pustaka Pelajar, Yogyakarta.

Sosok Sultan Badaruddin II di Uang Baru Rp.10.000, Vivanews.com, Diakses tanggal 1Februari 2011 pukul $22.00 \mathrm{WIB}$.

Teknik Pengumpulan dalam Analisis Data secara Kualitatif, Ivanovich Agusta, Makalah dalam pelatihan Metode Kualitatif di Pusat Penelitian Sosial Ekonomi, Bogor 27 Februari 2003.

Undang-undang Nomor 19 Tahun 2002 tentang Hak Cipta

Wawancara dengan Edy Jatmiko pada tanggal 14 April 2012

Wawancara dengan Baskoro Suryo Banindro pada tanggal 17 April 2012

Wawancara dengan P. Gogor Bangsa pada tanggal 15 April 2012 